Article

\title{
Europeanization of the World or Globalization of Europe?
}

\author{
Jerry Bentley \\ Department of History, University of Hawaii, Honolulu, Hawaii 96822, USA; \\ E-Mail: jbentley@hawaii.edu
}

Received: 25 April 2012; in revised form: 8 May 2012 / Accepted: 12 May 2012 /

Published: 14 May 2012

\begin{abstract}
Building on his long career as a distinguished historian of early modern Europe, John Miles Headley has recently turned his gaze to the influence of Europe in the larger world. In The Europeanization of the World, Headley makes an insistent case for the uniqueness of European values - particularly human rights and democracy-and argues that these values are Europe's most precious gifts to the larger world. Without seeking to diminish the remarkable intellectual and cultural achievements of European peoples, this presentation will suggest a more nuanced view of relations between Europe and the larger world. Human rights and democracy mean different things to different peoples in different contexts at different times, and there have in fact been numerous expressions of both in societies beyond Europe. Furthermore, European theorists of human rights and democracy drew influence from societies beyond Europe. To the extent that the Europeanization of the world is a persuasive idea, it is possible only because of a prior globalization of Europe.
\end{abstract}

Keywords: human rights; democracy; Renaissance; early modern Europe

Building on his long career as a distinguished historian of early modern Europe, John Miles Headley has recently turned his gaze to the influence of Europe in the larger world. In The Europeanization of the World, Headley makes an insistent case for the uniqueness of European values - particularly human rights and democracy — and argues that these values are Europe's most precious gifts to the larger world [1]. Without seeking to diminish the remarkable intellectual and cultural achievements of European peoples, this presentation will suggest a more nuanced view of relations between Europe and the larger world. Human rights and democracy mean different things to different peoples in different contexts at different times, and there have in fact been numerous expressions of both in societies beyond Europe. Furthermore, European theorists of human rights and 
democracy themselves drew inspiration from sources beyond Europe. To the extent that the Europeanization of the world is a persuasive idea, it is possible only because of a prior globalization of Europe.

In light of Headley's career as a distinguished historian of the Protestant and Catholic Reformations, it will be appropriate to begin this discussion with a scriptural text. The passage I have chosen comes from the book of Ecclesiastes, chapter 1, verses 9 and 10: "The thing that hath been, it is that which shall be; and that which is done is that which shall be done; and there is no new thing under the sun. Is there anything whereof it may be said, See, this is new? It hath been already of old time, which was before us" (AV). The words of the Preacher suggest the advisability of caution - second thoughts - to anyone making expansive claims for uniqueness and novelty in world history. Yet uniqueness is one of the defining characteristics of Headley's Europe. The terms "unique," "uniquely," and "uniqueness" make at least fifty appearances in his book, with all but five of these referring to the alleged distinctiveness of European values.

Headley's basic argument is simple and straightforward. Europe (or sometimes, more ambiguously, "the West") invented and developed two principles of universal significance: the idea of a common humanity, which underlies values of human rights and toleration, and the normalization of political dissent, which serves as the foundation of a free press and constitutional democracy. Both principles built on intellectual foundations stretching back as far as Socrates and the ancient Stoics, Headley argues, but both of them achieved distinctive formulations in the early modern era. The notion of a common humanity emerged in the sixteenth century, as European mariners visited all parts of the world that were accessible through the seas, prompting the construction of the notion that humanity is a single biological and moral community. The acceptance of political dissent began to take on institutional form in the seventeenth century with the emergence of party politics, constitutions, and concepts of popular sovereignty. Headley holds that both principles - the idea of a common humanity and the normalization of political dissent - underwent continuous and sustained development during the period 1500 to 1800 . He readily acknowledges that similar moments occurred in other societies, albeit briefly and intermittently — in the work of Mencius and Akbar, for example — but he maintains that there was no sustained development or institutionalization of human rights or democracy in other lands. He harbors no illusions about the moral superiority of Europe. He acknowledges clearly and repeatedly that Europeans have perpetrated horrible atrocities both on fellow Europeans and on other peoples. Yet he holds also that Europe has been the target of undue criticism, and he maintains firmly that the European values of human rights and democracy merit respect and appreciation as gifts to humanity. This one-paragraph summary cannot do justice to the depth, subtlety, and sophistication of Headley's analysis, but I hope it at least represents fairly the major arguments of his book.

One peculiarity of Headley's book on The Europeanization of the World is that it actually has little to say about the world beyond Europe. The principal task of the book is to trace the intellectual history of the ideas of human rights and democracy in European context. Headley accomplishes this task in most impressive fashion: indeed, his book represents a tour de force of conventional intellectual history by patiently following strands of ideas from ancient through medieval to early modern times, tracing their influence on successive generations of thinkers, and recounting their gradual assemblage into the modern ideas of human rights and democracy. If this sounds like a whiggish approach, it is. 
But it also represents a sensitive and detailed review of two ideas that have profoundly influenced European and North American historical experience.

Nevertheless, in light of his expansive title-The Europeanization of the World - it is surprising that only on page 193 (out of 218 pages of text) does Headley raise the question: "But what of the world beyond Europe?" It is even more surprising that the following pages have more to say about European views on the world beyond Europe than about the world beyond Europe itself. Headley's book actually deals with the Europeanization of Europe, not at all with the Europeanization of the world, which would presumably involve the widespread adoption of European human rights values and democracy in the larger world. ${ }^{1}$ Judging from the topics and issues that Headley chooses to discuss, the Europeanization of the world would seem to be a future prospect - a development that might eventually take place, and a development that will be able to draw on pre-existing cultural elements in the world's various societies (e.g., the work of Mencius and Akbar) as well as European constructs - but it is not a development that has already taken place and that accordingly might be susceptible to historical review and analysis.

The recognition that Headley's book deals with the Europeanization of Europe rather than the Europeanization of the world suggests a question: What if we take the larger world more seriously and examine developments in the larger world on their own terms, rather than relying exclusively on European constructions of the larger world? Historians once considered Europe a unique site of exceptional traits, including reason, enterprise, innovation, creativity, organizational talent, rule of law, and risk-taking behavior, and they even held that the European demographic regime was unique in that Europeans practiced birth control and sought to limit population expansion more than other peoples. As scholars have looked beyond Europe and conducted serious research in other parts of the world, however, they have exposed these vague notions about Europe's supposed uniqueness as speculative myths, misunderstandings, or self-congratulatory conceits that bear limited resemblance to historical reality as historians have best been able to construe it. Most of these conceits represent the residue of Hegelian ideology as professional historians absorbed it in the nineteenth century. Only since about 1950 have historians and area studies experts undertaken the herculean effort that has generated better and more reliable knowledge about the larger world. In the context of the vast library of scholarship they have produced on the world beyond Europe, it has become clear that Europe was far less unique, in any meaningful sense of the term, than earlier generations of historians supposed.

What about the issues of human rights and democracy? When considered in global context, will they melt away under the harsh, unblinking glare of historical analysis like the other supposedly unique traits of European peoples? In their favor, the ideas of human rights and democracy have a higher degree of specificity than the earlier-cited list of vague qualities frequently attributed to Europe. Certainly no historian will ever discover a premodern Asian analogue to Locke's Second Treatise of Civil Government or an ancient African equivalent of the Universal Declaration of Human Rights, just

1 In Headley's case, this term would mean something different from the earlier "Europeanization of Europe" discussed by Robert Bartlett who believed it meant the spread of Christian cultural elements, administrative practices, and institutionalized education from the core European region of the former Carolingian empire to more peripheral regions ([2], pp. 269-91). Yet if Headley were to frame his argument in terms of an Europeanization of Europe rather than the world, the process he describes might well seem to be an extension or deepening of Bartlett's Europeanization. 
as none will ever discover the European correspondent to the Confucian Analects or the Bhagavad Gita. The specific features of cultural traditions are obviously unique to the peoples who created them. It would be pointless to expect peoples of other societies and cultural traditions to formulate doctrines of human rights or democracy that are precise parallels of European doctrines. This kind of uniqueness is undoubtedly important: it is the kind of uniqueness that makes history possible, since unique developments and experiences are the very stuff and matter of historical analysis. In this sense of the term, every society, every individual is unique, and nobody will even begin to doubt that that is true.

Headley's uniqueness, however, is altogether different in character. When he discusses the uniqueness of European values, he has in mind something more like exceptionalism rather than the everyday uniqueness that historians routinely deal with in their work. His conception of European uniqueness implies the claim that European agents elaborated particular values that are so wholly unlike and so fundamentally different from those found anywhere else that they had no proper counterparts in the larger world and hence are not even comparable to values elaborated in the world beyond Europe. Consideration of European uniqueness in Headley's strong sense of the term requires attention to two questions about historical developments in the world beyond Europe: First, whether societies beyond Europe may have developed some functional equivalents of human rights and democracy that served similar purposes, even if they did not achieve the same formulations that they did at European hands? And second, whether the European formulations of human rights and democracy may have drawn on influences and inspirations from the world beyond Europe? In both cases, I respond that the answer to these questions is Yes.

Democracy and efforts to promote democracy have obviously loomed large in world affairs over the past quarter-century. It is a disappointment that historians have had little to say about democracy, leaving the task largely to political scientists, philosophers, and legal scholars. Headley is one among the few, the proud, the brave among historians who have taken up the challenge of analyzing democracy in historical context. This task is difficult for several reasons: there is no objective standard to measure what does or does not count as democracy; since the twentieth century, the term democracy has figured so prominently in ideological disputes that its very use raises different assumptions in different minds; like any other concept laden with moral implications, democracy does not lend itself to the kind of precise analysis that is possible for measures of wheat, jugs of wine, bolts of cloth, and other items studied by historians of the material world; and moreover, perhaps most importantly, democracy is a word with deep emotional power that brings visions of hope to some while striking fear in the hearts of others and prompting very different assumptions and historical analyses in all cases. That does not mean that historians should not analyze democracy in historical context. Quite the contrary: as a profoundly influential historical phenomenon, democracy is far too important to leave to the tender mercies of political scientists, philosophers, and lawyers (with all due respect to these distinguished scholars for the contributions that they have been able to make from their own vantage points).

When thinking about democracy in global historical context, it is or should be clear that it will have different characteristics at different times and in different places. Bicameral legislatures with regular schedules of full, free, fair, and unobstructed elections were rare features anywhere in the world before the twentieth century. If these were the criteria for democracy, no part of the USA was democratic before passage of the Nineteenth Amendment guaranteeing women's suffrage in 1920, and some 
regions would not qualify as democratic until after the passage of the Voting Rights Act of 1965. Granting that bicameral legislatures with regular schedules of full, free, fair, and unobstructed elections are absolutely wonderful and admirable institutions, we clearly need more flexible criteria if we want to hold a fruitful conversation about democracy on a cross-cultural and global basis. What kinds of institutions and practices might qualify as functional equivalents of contemporary democracy?

Amartya Sen has considered this question in especially illuminating fashion. Following John Rawls in particular among others, Sen views democracy less as a matter of establishing specific institutions or even voting than of exercising public reason and making a place for individuals to participate in public decisions that affect their lives and livelihoods. "Public reasoning," he explains, "includes the opportunity for citizens to participate in political discussions and to influence public choice. Balloting can be seen as only one of the ways - albeit a very important way - to make public discussions effective, when the opportunity to vote is combined with the opportunity to speak and listen, without fear" ([3], p. 14). By this standard, democracy in some form or another is by no means the exclusive preserve of Europe and its North American offshoots. Athens and Rome were certainly early laboratories of democracy, but Sen argues persuasively that India also has long been a site for the exercise of public reason. From the time of the ancient Himalayan republics through the early Buddhist councils and the imperial courts of Ashoka and Akbar to the present day-for the better part of three millennia - south Asia has been a forum for the exercise of public reason. Nor was India the only such forum. Sen argues that the Buddhist values that emanated from ancient India inspired similar practices in other lands where Buddhism found a large following. He cites the case of the Japanese Buddhist Prince Shotoku, to mention only one example among many, who in the early seventh century implemented a constitution providing that "Decisions on important matters should not be made by one person alone. They should be discussed with many" ([3], pp. 81-82).

Historians Steven Muhlberger and Phil Paine adopted a similar approach in their exploratory sketch of "Democracy's Place in World History" [4]. Focusing their attention on local rather than royal, imperial, or national levels of organization, Muhlberger and Paine argue that over the long run of history politics has been mostly a local affair, that councils and assemblies organized on a village or kinship basis have tended to most of the governmental and decision-making matters that impinge directly on the lives and livelihoods of individuals, and that these councils and assemblies have operated in large measure on democratic or quasi-democratic principles to the extent that discussion, consultation, debate, negotiation, and often voting informed public decisions. The authors adduce cases from China, India, sub-Saharan Africa, and native societies in North America to substantiate their argument that local practice has depended on a kind of rough, de facto democracy in much of the world beyond Europe.

The kind of democracy that Sen, Muhlberger, and Paine have in mind is clearly not the equivalent of contemporary democracy, nor did it confer the kind of protections that individuals properly expect from contemporary democracy (at least when it functions well). Unlike de facto democracies in other parts of the world, contemporary democracy rooted in Europe benefits from deep intellectual traditions and powerful institutions that inform and sustain this strain of government, and one of the merits of Headley's book is precisely to sort out the lineages of these intellectual traditions.

Yet the works of Sen, Muhlberger, and Paine help to make two points clear. First, when talking about the world, it is crucial for historians to resist temptations to restrict their horizons to story lines 
that are familiar from European experience. It is essential for them to go further and undertake the difficult work of actually investigating historical reality in the larger world, just as professional historians from Leopold von Ranke forward have compiled remarkable histories of Europe and its American offshoots. Second, if they are going to talk about democracy in global context, it is essential for historians to recognize the fact that democracy will take different shapes and sport different colors in different societies. To take one cultural expression as the Ideal Type of Democracy, or as the standard against which all the others get measured and inevitably found wanting, is tantamount to a foreclosure on any opportunity for investigation, analysis, discussion, or debate about the nature and history of democracy itself. ${ }^{2}$ When historians venture from Europe into the larger world, it is essential that they open their minds to the reality that different peoples in different societies have different rationalities that do not necessarily benefit from being judged against European standards. By this light, European peoples elaborated a remarkable and admirable strain of democracy, but that does not necessarily mean that democracy per se is a purely European gift to the world. Rather, it will be more helpful to think of democracy-like agriculture, perhaps - as an ever-changing and constantly evolving product of multiple independent inventions by different peoples in different world regions at different times and under different sets of circumstances.

Even in cases of multiple independent inventions, there is abundant scope for different individual traditions to influence the development of others. Indeed, this is the prospect that Headley's book envisions with respect to European values of human rights and democracy in the larger world. Here I would like to suggest that outside influences played a role in the development of some values in Europe itself. When it came to democracy, of course, Europeans were able to build on distinctive elements from classical antiquity and the medieval era. When it came to toleration and human rights, however, ancient and medieval experience offered them much less positive or constructive guidance. Thus, where their own cultural and intellectual tradition was lacking, European theorists of toleration and human rights drew inspiration from other wells. One source was the purely practical experimentation with a limited religious toleration that Dutch authorities tried in the interests of maintaining public order in their own multi-confessional environment [6]. Another was the kind of everyday practice of tolerance that members of communities often extended to their fellows as recently outlined by Stuart B. Schwartz [7]. Yet another, which will be my focus here, was the longinstitutionalized practice of religious toleration in the world of Islam, which European peoples learned about through the reports of travelers who commented on customs and conditions in the lands they visited. None of these sources of inspiration has figured prominently in conventional approaches to intellectual history, which quite simply has not gotten us very far in understanding the influences that helped to bring about policies of religious toleration. Yet these sources are essential for a proper historical understanding of religious toleration and human rights. Analysis of these sources of inspiration and their influences on emerging theories of toleration calls for the exploration of historical sources that intellectual historians have not previously taken into consideration.

2 Donald Treadgold takes exactly this approach. While claiming to deal with "the history of freedom on a world scale within a single pair of covers," he devotes his attention almost exclusively to Europe and North America, and he takes European conceptions of freedom as the de facto standards of freedom (including democracy and human rights) ([5], p. 2). 
Historians have of course long recognized that European scholars avidly consumed the works of Muslim philosophers and scientists during the middle ages, particularly in the twelfth and thirteenth centuries. There has been less attention to the possibility of any continuing influence in early modern times. As conventionally practiced, intellectual history has made limited contribution thus far to the understanding of this issue. The task is not simply a matter of tracing the genealogy and the handling of individual ideas through a series of European intellectual agents - the forte of conventional intellectual history - but rather of spotting influences that arrived by unusual routes and that European theorists might well have intentionally obscured.

A case in point comes from recent studies of a philosophical novel by Ibn Tufayl and its influence in early modern Europe. Ibn Tufayl was a twelfth-century physician and political advisor at the court of the Almohad Sultan Abu Ya'qub Yusuf of Morocco and Spain. He was a companion of Ibn Rushd (Averroes) whom he in fact invited to reside at the sultan's court. About 1160 or 1170 Ibn Tufayl wrote his novel Hayy Ibn Yaqzan - the name means "living son of the wakeful"- a boy abandoned as an infant who grew up on a tropical island with no other human inhabitants. Nursed through youth by a kindly doe gazelle, Hayy discovered on his own how to control fire, build shelter, domesticate animals, and invent tools. Later, on the basis of nothing more experimentation and reason, he became a physician, astronomer, and philosopher. Thus he was eventually able to reason his way to an understanding of the world and even to the existence of God. In the last pages of the novel Hayy encountered a wise hermit, who introduced him to the outside world. But Hayy found it profoundly unappealing because its inhabitants led their lives on the basis of doctrine and dogma instead of reason and experimentation, so he soon abandoned human society and returned to his island [8].

The story of Hayy caught the attention of free thinkers in Europe from the fourteenth century. Moses of Narbonne made a Hebrew translation in 1349, and Pico della Mirandola made a Latin translation on the basis of Moses's Hebrew in the late fifteenth century. During the seventeenth and eighteenth centuries, Ibn Tufayl's influence soared. In 1671 Edward Pococke the younger-son of Edward Pococke, the first Laudian professor of Arabic at Oxford University - published the first Latin translation (which he had prepared under his father's supervision) directly from Ibn Tufayl's Arabic under the title Philosophus autodidactus. Translations into Dutch, English, French, and other languages followed shortly thereafter, and Ibn Tufayl's book became quite the rage in England as well as the Continent. It is likely that the story of Hayy was the model or inspiration or point of departure for Daniel Defoe's account of Robinson Crusoe, and Ibn Tufayl's influence is clearly traceable in Spinoza, Leibniz, Pope, Bayle, and Diderot, among others ([9], pp. 628-31; [10]).

Was Ibn Tufayl's novel also a source of inspiration for John Locke's Essay on Human Understanding? There is no absolute documentary proof, but G.A. Russell has advanced a powerful and persuasive argument on this point. She points out that before 1671, Locke's interests included political and social but not epistemological or psychological issues. In 1671, however, he began the initial work on the treatise that eventually appeared in 1690 as the first edition of the Essay on Human Understanding. From 1652 to 1667 Locke lived principally at Oxford, where he was an outspoken admirer and a very close personal friend of Edward Pococke the elder as well as a tutor (1660-1661) to Edward Pococke the younger. Although Locke's library does not seem to have included a copy of Ibn Tufayl in Pococke's Latin translation, it is quite literally inconceivable that he was unaware of the book at precisely the time he began his own epistemological work. It certainly would be a remarkable 
coincidence - a little too much coincidence for my own comfort - that just at the moment his close friends produced a Latin translation of Ibn Tufayl's novel, Locke began to think totally independently about the human mind as a tabula rasa that progressed to understanding on the basis of sense experience and reason ([11], 224-65; [12]). ${ }^{3}$

The prospect that an obscure medieval Muslim philosopher might have sparked a foundational idea in a luminary such as John Locke is a notion that nobody would have even wasted time contemplating only a few years ago. Yet now it seems all but certain that Ibn Tufayl did indeed strike a chord with Locke and provide him with the kernel of an idea that he later developed in his own way and according to his own genius. Is it possible that additional influences came from the Muslim world or elsewhere to spark ideas among European thinkers who then worked them into formulations that have become familiar to us as human rights theory? More broadly, to what extent might peoples beyond Europe have contributed to the development of modern thought about human rights?

Throughout the early modern era-from the earliest fourteenth-century ventures to the nearby Atlantic islands and fifteenth-century soundings in west Africa through sixteenth- and seventeenthcentury explorations in the Americas and Asia to eighteenth-century reconnoitering of the Pacific Ocean basin - an avalanche of information about the larger world poured into Europe. Merchants, missionaries, conquerors, settlers, and other travelers deluged European readers with their reportage on previously undescribed lands and peoples. Among the many strange and outlandish customs reported in this body of literature was the practice of religious toleration already observed for almost a thousand years in Muslim lands. We know for a fact that many of these travel accounts made their way to the notice of influential readers - including John Locke among others.

An early example of this reportage came from the accounts of three men who were some of the earliest Englishmen to travel extensively in Mughal India: Sir Thomas Roe, Edward Terry, and Thomas Coryat. Roe was the first English resident ambassador to India, serving as emissary of King James I to the Mughal court from 1615 to 1619. Terry was Roe's chaplain for most of his time in India. Coryat was a writer and traveler — neither merchant nor emissary — who spent five years (1612 to 1617) visiting various Muslim lands with an eye toward writing an account to follow up on his popular description of his earlier travels through Europe, Coryat's Crudities. These three were some of the earliest Englishmen who had the opportunity to spend considerable time in India and observe the Mughal court and society from perspectives outside the trade factories of the East India Company. They knew each other well and sometimes traveled together as they followed the Mughal court. All three portrayed the current emperor, Jahangir, as fair and generous of spirit, while characterizing his father and predecessor, Akbar, in similar terms. All three also commented specifically and with a notable degree of wonder on the policy of religious toleration that prevailed in Mughal India.

During the course of his embassy, Roe addressed at least two letters to George Abbot, Archbishop of Canterbury and brother of Roe's friend Sir Maurice Abbot, who was Deputy-Governor of the East India Company. In one notable letter of 30 October 1616, Roe focused his attention on religious affairs

Although lacking the translation of Ibn Tufayl, Locke's library lacked the translation of Ibn Tufayl, but included three commentaries by Edward Pococke the elder on the books of Hosea, Joel, and Micah in the Hebrew Bible ([13], p. 212). Locke of course made no mention of Ibn Tufayl in his famous essay, but he illustrated his point with several references to conditions in the Muslim world ([14], pp. 71-72, 94, 657, 708). 
in the Mughal Empire. He reported (mistakenly) that Timur and his descendants introduced Islam to India "but imposed it vpon none by law of Conquest, leauing consciences at liberty." He noted that alongside "strict Mahometans" (Sunni), there were others who were followers of Ali (Shiites) as well as numerous other sectarians following their own preferred prophets (presumably Sufis). Thus he characterized Islam as "a mingled religion, not vpright with their great Prophett." But that was just the Muslim population of India. The "Gentilles" population was even more diverse, including some who would drink wine, others who would eat swine, some who worshipped beasts, a few who would not even swat away the insects that attacked them, and many who refused to associate with certain others on the basis of their rank. The whole he characterized as "a Confusion." The confusion only became more complex after Akbar sponsored the presence of Roman Catholic missionaries and debates between Hindu, Muslim, and Christian representatives. Akbar even permitted conversion to Christianity, a policy continued by Jahangir, whom Roe characterized as "Content with all religions" and respectful toward every sect. Roe himself never doubted the truth of Christianity in the form of his own inherited Anglican confession, and he did not refrain from offering up numerous barbs about the aims and work of the Roman Catholic delegation in India. Yet he also made available to his readers a mostly fair (albeit sometimes inaccurate) characterization of a powerful and prosperous society that consciously followed a policy of religious toleration ([15], 2, pp. 308-19).

Thomas Coryat died in India and so was unable to compose the account of travels through Muslim lands that he hoped to provide, but several letters survive from his days in India. They confirm and build upon the image of India advanced by Roe. Coryat confirmed Jahangir's friendliness to Christians, noting that the Mughal emperor referred to Jesus as "Great Prophet Jesus." He related a story about Akbar to emphasize his tolerance and fair-mindedness: After certain Portuguese had tied a copy of the Quran around a dog's neck and chased it around the city of Agra, Akbar's dear mother reportedly suggested that he retaliate by tying a copy of the Bible around another dog's neck and chasing it through the streets of Hormuz. "But hee denyed her request, saying that, if it were ill in the Portugals to doe so to the Alcoran, being it became not a King to requite ill with ill, for that the contempt of any religion was the contempt of God, and he would not be revenged upon an innocent booke." Coryat also recounted his own quite amazing experience. After a Muslim insulted him by calling him an infidel, Coryat replied with a lengthy impromptu oration in which he publicly denounced Muhammad as a false prophet, the Quran as the work of a Byzantine monk named George, Muslim prayers as offenses before God, and the Muslim paradise as "a filthy quagmire ... full of stincking dung-hills," among other broad slurs. Not one to restrain himself in the manner of Akbar, Coryat at least recognized both the riskiness of his action and his good judgment in choosing the Mughal realm as the venue for his denunciations: "If I had spoken thus much in Turky or Persia against Mahomet, they would have rosted me upon a spit; but in the Mogols dominions a Christian may speake much more freely then hee can in any other Mahometan country in the world" ([16], pp. 246, 271, 273, 278).

Coryat placed his trading of insults in the prominent commercial city of Multan (modern-day western Pakistan, south of Lahore), while Edward Terry attributed a similar confrontation to him at Agra, the Mughal capital south of Delhi. There, according to Terry, Coryat took offense at the proclamation that there is no God but God and that Muhammad is the prophet of God. "Which words Master Coryat often hearing in Agra, upon a certaine time got up into a turret, over against the priest, 
and contradicted him thus in a loude voice: la Alla, illa Alla, Hazaret-Eesa Ebn-Alla: No God but one God, and Christ the sonne of God; and further added that Mahomet was an imposter; which bold attempt in many other places of Asia, where Mahomet is more zealously professed, had forfetted his life with as much torture as tyrannie could invent. But here every man hath libertie to professe his owne religion freely and, for any restriction I ever observed, to dispute against theirs with impunitie." Elsewhere chaplain Terry affirmed that in the Mughal realm "All religions are tolerated, and their priests in good esteeme, My selfe often received from the Mogoll himself the appellation of Father, with other many gracious words, with place amongst his best nobles."

The accounts of Roe, Coryat, and Terry were only three among thousands of travel reports that reached Europe during the early modern era. Why pay so much attention to this trio? Although their names are obscure today, the works of all three men reached audiences of influential readers. Samuel Purchas included excerpts from all three men's works in his collections of travel accounts, Purchas, his Pilgrimage and its successor volumes, which were of course wildly popular in the seventeenth and eighteenth centuries. John Locke's library included a copy of Purchas as well as a separate copy of Terry's book ([13], pp. 216, 245). ${ }^{5}$ Quite apart from Purchas, Coryat's letters and Terry's report appeared independently in seventeenth-century editions, and Roe's journal in an eighteenth-century edition. Coryat's letters made the rounds at the Mermaid Tavern near St. Paul's Cathedral. He was a regular at the Friday Street Club there - a group with an illustrious membership, including Ben Jonson, John Donne, Inigo Jones, Sir Robert Cotton, Samuel Purchas, and John Selden, the most outspoken Englishman advocating religious toleration in the early seventeenth century. (Coryat addressed two of his letters from India to Laurence Whitaker, "the High Seneschall of the Right Worshipfull Fraternitie of Sireniacal Gentlemen, that meet the first Fridaie of every moneth at the signe of the Mere-Maide in Bread-streete in London," for transmission to his friends at the tavern ([16], pp. 241-52, 256-58). So far as I can see, Selden did not make use of any intelligence about the Muslim world in making his own case for religious toleration. Yet his fundamentally Erastian approach had as its aim a regime of managing public order that was not at all unlike the system that Akbar and Jahangir supervised in Mughal south Asia. ${ }^{6}$

Eventually, however, information about religious toleration in Muslim lands quite clearly made its way into works by some of the most prominent architects of toleration theories. By the late seventeenth century, it was commonplace for European theorists to compare Muslim policies of toleration favorably against Christian intolerance ([18], pp. 393-95). To mention only two particular luminaries, John Locke and Pierre Bayle both went to considerable lengths to learn about conditions in the Islamic world, and they both took a noticeable and particular delight in pointing out that Muslims, Jews, and Christians of all confessions-Roman Catholic, Orthodox, Lutheran, Calvinist, Arminian, and others - were free to practice their faiths openly in Muslim lands while Christian European lands

4 See Terry's account of his experiences in India, which was composed probably about 1620 or 1621, reprinted in [16], quoting from pp. 315 and 331.

5 Locke also possessed copies of works by other prominent travelers, such as François Bernier and Paul Rycaut, who reported on the world of Islam. It is quite clear that he valued information about conditions in the Islamic empires.

6 Selden's table talk is full of comments to the effect that there can be no objective determination as to which religion is better than the others, so that the state must serve as referee and ensure that harmony prevails in a society hosting multiple religious communities ([17], pp. 9, 79, 161-67). 
restricted religious freedom to a narrow range of confessions at best. As Locke proposed in his Letter Concerning Toleration (1689), "let us suppose two churches, the one of Arminians, the other of Calvinists, residing in the City of Constantinople. Will any one say, that either of these churches has right to deprive the members of the other of their estates and liberty, as we see practised elsewhere, because of their differing from it in some doctrines or ceremonies; whilst the Turks in the meanwhile silently stand by, and laugh to see with what inhuman cruelty Christians thus rage against Christians?" ([19], pp. 224-25). ${ }^{7}$ In his entry on "Mahomet" in Le Dictionnaire historique et critique (begun in 1695), Bayle compared Christianity and Islam with respect to toleration: "The Mahometans, according to the principles of their faith, are obliged to employ violence, to destroy other religions, and yet they tolerate them now, and have done so for many ages. The Christians have no order, but to preach, and instruct; and yet, time out of mind, they destroy, with fire and sword, those who are not of their religion." Indeed, Bayle attributed the very survival of Orthodox Christianity to its good fortune to have fallen under Muslim domination: "It may be affirmed for a certain truth, That if the western princes had been lords of Asia, instead of the Saracens and Turks, there would be now no remnant of the Greek church, and they would not have tolerated Mahometism, as these Infidels have tolerated Christianity" ([21], pp. 38-39, 349-50).

Could the European value of religious toleration have emerged in the absence of the Muslim example of toleration? Yes, undoubtedly. Persecuted souls like Sebastian Castellio put out the call for toleration evidently without benefit of knowledge about conditions in the Muslim world, and the Dutch example suggests that purely practical considerations of social stability might well have pushed European peoples in the direction of toleration even if they didn't particularly like the idea and even though there was limited foundation in European tradition to build upon. The historical record is so full of contingency and unpredictable chance developments that it would not be wise to preclude the possibility that a European theory of toleration might have arisen on the basis of purely indigenous elements. Counter-factual considerations to the contrary notwithstanding, in the event, the Muslim example did indeed play a role in the gradual emergence of toleration theories during the early modern era and the European Enlightenment [18]. ${ }^{8}$

But the Enlightenment was by no means the end of influence from beyond Europe on human rights doctrine. To the contrary, advocates from African, Latin American, and especially Asian lands played crucial roles in bringing about the crowning achievement of the human rights movement — adoption of the Universal Declaration of Human Rights (UDHR) by the United Nations on 10 December 1948. Conventional treatments present the UDHR as the result of European and North American initiative inspired by the political values of the Enlightenment and the democratic revolutions [27]. Yet a minor spate of recent studies has demonstrated convincingly that Asian, African, and Latin American lobbyists pushed for human rights conventions much faster than their European and North American counterparts.

\footnotetext{
In his second, third, and fourth letters on toleration, Locke continued to invoke the example of Muslims [20]. On purely religious grounds he argued the futility of persecution, explaining that every religion and every church is orthodox unto itself, but heretical in the eyes of others.

8 Apart from Marshall's very brief notice [18], existing historical scholarship on religious toleration [22-26] totally ignores extra-European influences.
} 
Adoption of the UDHR did not represent the first (or last) international consideration of human rights issues. Well before adoption of the UDHR, the First Universal Races Congress (1911), the Paris Peace Conference (1919), and the Dumbarton Oaks Conference (1944), among others, all heard calls for human rights under the rubrics of racial equality and self-determination of peoples as well as civil, political, economic, social, and cultural rights. In all cases, European and North American representatives resisted efforts by Asian, African, and Latin American delegates to advance policies of racial equality and self-determination. Intellectual and diplomatic foot-dragging on these issues continued well into the 1960s. Adoption of the UDHR was both necessary and possible in 1948 precisely because European and North American representatives had successfully stalled the recognition of human rights values on multiple occasions beforehand [28-30].

Who were the advocates for human rights before adoption of the UDHR, and what causes did they promote? Recent scholarship has emphasized two issues - freedom of movement and racial equalityas prominent aims of human rights advocates outside Europe. Japanese and especially Chinese activists asserted their "common human rights" from the 1870s, as discriminatory immigration laws restricted their mobility in violation of international treaties and sometimes even imperial policies. Racial equality, which implied equality of nations in the international order, was a goal dear to the hearts of Japanese and Chinese peoples in the era of the unequal treaties during the later nineteenth and early twentieth centuries. Japanese delegates to the Paris Peach Conference lobbied famously but unsuccessfully with Chinese support for the League of Nations to embrace racial equality as a founding principle. Chinese were perhaps even more active in the promotion of international racial equality, especially after Japan managed to escape the burdens of the unequal treaties following victory in the Sino-Japanese War of 1894 to 1895 . Their argumentation was eclectic, drawing influence sometimes from Christianity, Enlightenment theories, and international law, but also relying on the long tradition of Chinese civilization and the Confucian principles of reciprocity and mutual respect, while also reflecting the practical grievances of communities inconvenienced by human rights violations [31,32]. Thus Chinese advocacy of human rights was emphatically not a borrowed or derivative discourse. Rather, as two scholars have put it, "discussion of rights in China has long been motivated by indigenous concerns, rather than imposed from without, and it has been interpretive and critical, rather than passive and imitative" ([32], p. xiii). More broadly, in the words of the best contemporary historian of human rights: "The historical origins of powerful visions capable of shaping world events and attitudes like those of international human rights are rarely simple. Instead, they emerge in complicated and interrelated ways from the influence of many forces, personalities, and conditions in different times and diverse settings, each flowing in its own unique way like tributaries into an ever larger and mightier river" ([28], p. 4).

Indeed, neither democracy nor human rights is an exclusively European invention. Functional equivalents have long been prominent in the world beyond Europe, and peoples from the larger world have made their own contributions to the recognition of democracy and human rights as we understand them today in the international community. In this presentation I have mentioned only a few routes by which knowledge and influence flowed from the larger world into Europe and North America, and I have mentioned only a few individuals from the world beyond Europe who contributed to the formulation of contemporary values. This is the case because only recently have historians even begun to consider it worth their while to investigate expressions of democracy and human rights beyond 
European and North American horizons. We simply do not yet have the foundation in basic research to present a fully fleshed account of democracy and human rights in all world regions.

European and North American peoples have been conspicuous in their own efforts on behalf of democracy and human rights, and I have absolutely no wish to minimize or disparage their contributions. But the time has come, in the interests of clear historical understanding unclouded by Eurocentric mythologies, to take the larger world seriously, to scour global archives just as assiduously as historians have examined the European record over the past two centuries, and to follow as clearly as Headley has done for Europeans the contributions that peoples beyond Europe have made to the development of democracy and human rights.

\section{Acknowledgements}

Thanks are due to Professors Constantin Fasolt, Lloyd S. Kramer, Daniel W.Y. Kwok, and John Jeffries Martin for their comments on a previous version of this essay.

\section{References}

1. John M. Headley. The Europeanization of the World: On the Origins of Human Rights and Democracy. Princeton, NJ: Princeton Univ. Press, 2008

2. Robert Bartlett. The Making of Europe: Conquest, Colonization and Cultural Change, 950-1350. Princeton, NJ: Princeton Univ. Press, 1993.

3. Amartya Sen. The Argumentative Indian: Writings on Indian History, Culture and Identity. New York, NY: Farrar, Straus and Giroux, 2005.

4. Steven Muhlberger and Phil Paine. "Democracy's Place in World History." Journal of World History 4 (1993): 23-45.

5. Donald W. Treadgold. Freedom: A History. New York, NY: New York Univ. Press, 1990.

6. Charles H. Parker. "Paying for the Privilege: The Management of Public Order and Religious Pluralism in Two Early Modern Societies.” Journal of World History 17 (2006): 267-96.

7. Stuart B. Schwartz. All Can Be Saved: Religious Tolerance and Salvation in the Iberian Atlantic World. New Haven, CT: Yale Univ. Press, 2008.

8. Ibn Tufayl's Hayy Ibn Yaqzan, translated by Lenn E. Goodman. New York, NY: Twayne, 1972.

9. Jonathan Israel. Enlightenment Contested: Philosophy, Modernity, and the Emancipation of Man, 1670-1752. Oxford: Oxford Univ. Press, 2006.

10. Samar Attar. The Vital Roots of European Enlightenment: Ibn Tufayl's Influence on Modern Western Thought. Lanham, MD: Lexington Books, 2007.

11. G.A. Russell. "The Impact of the Philosophus Autodidactus: Pocockes, John Locke, and the Society of Friends." In The 'Arabick' Interest of the Natural Philosophers in Seventeenth-Century England, edited by G.A. Russell. Leiden: Brill, 1994, 224-65.

12. G.A. Russell. "Ibn Tufayl's Hayy ibn Yaqzan and Locke's Essay on Human Understanding: Further Evidence," Journal of the History of the Neurosciences 19 (2010): 53-54.

13. John Harrison, and Peter Laslett. The Library of John Locke, 2nd ed. Oxford: Clarendon Press, 1971. 
14. John Locke. An Essay Concerning Human Understanding. Edited by P.H. Nidditch. Oxford: Clarendon, 1975.

15. Sir Thomas Roe. The Embassy of Sir Thomas Roe to the Court of the Great Moghul, 1615-1619. Edited by William Foster. London: Hakluyt Society, 1899, 2 vols.

16. William Foster, ed. Early Travels in India, 1583-1619. London: Oxford Univ. Press, 1921.

17. Samuel Harvey Reynolds, ed. The Table Talk of John Selden. Oxford: Clarendon Press, 1892.

18. John Marshall. John Locke, Toleration and Early Enlightenment Culture. Cambridge, UK: Cambridge Univ. Press, 2006.

19. John Locke. “A Letter Concerning Toleration.” In Two Treatises of Government and A Letter Concerning Toleration, edited by Ian Shapiro. New Haven, CT: Yale Univ. Press, 2003, 224-25.

20. Nabil Matar. "John Locke and the 'Turbanned Nations,"' Journal of Islamic Studies 2 (1991): 67-77.

21. Pierre Bayle. The Dictionary Historical and Critical of Mr Peter Bayle, 2nd ed. London: J.J. and P. Knapton, 1734-38, vol. 4.

22. W.K. Jordan. The Development of Religious Toleration in England. Cambridge, MA: Harvard Univ. Press, 1932-1940, 4 vols.

23. Roland Bainton. The Travail of Religious Liberty. Philadelphia, PA: Westminster, 1951.

24. Joseph Leclerc. Toleration and the Reformation. New York, NY: Association Press, 1960, 2 vols.

25. Henry Kamen. The Rise of Toleration. New York, NY: McGraw-Hill, 1967.

26. Perez Zagorin. How the Idea of Religious Toleration Came to the West. Princeton, NJ: Princeton Univ. Press, 2003.

27. Lynn Hunt. Inventing Human Rights: A History. New York, NY: Norton, 2007.

28. Paul Gordon Lauren. The Evolution of International Human Rights: Visions Seen, 2nd ed. Philadelphia, PA: Univ. of Pennsylvania Press, 2003.

29. Kenneth Cmiel. "The Recent History of Human Rights." American Historical Review 109 (2004): 117-35.

30. Roland Burke. "'The Compelling Idea of Freedom': Human Rights at the Bandung Conference." Human Rights Quarterly 28 (2006): 947-65.

31. Marilyn Lake. "Chinese Colonists Assert Their 'Common Human Rights': Cosmopolitanism as Subject and Method of History.” Journal of World History 21 (2010): 375-92.

32. Stephen C. Angle, and Marina Svensson, eds. The Chinese Human Rights Reader: Documents and Commentary, 1900-2000. Armonk, NY: M.E. Sharpe, 2001.

(C) 2012 by the author; licensee MDPI, Basel, Switzerland. This article is an open access article distributed under the terms and conditions of the Creative Commons Attribution license (http://creativecommons.org/licenses/by/3.0/). 